\title{
Family history of mental conditions in the preventive paediatric primary care: is it really used? Case of the Netherlands
}

\author{
Citation for published version (APA):
}

Syurina, E. V., Hens, K., Dondorp, W. J., \& Feron, F. J. M. (2014). Family history of mental conditions in the preventive paediatric primary care: is it really used? Case of the Netherlands. Acta Paediatrica, 103(3), 309-313. https://doi.org/10.1111/apa.12521

Document status and date:

Published: 01/01/2014

DOI:

10.1111/apa.12521

Document Version:

Publisher's PDF, also known as Version of record

\section{Document license:}

Taverne

Please check the document version of this publication:

- A submitted manuscript is the version of the article upon submission and before peer-review. There can be important differences between the submitted version and the official published version of record.

People interested in the research are advised to contact the author for the final version of the publication, or visit the DOI to the publisher's website.

- The final author version and the galley proof are versions of the publication after peer review.

- The final published version features the final layout of the paper including the volume, issue and page numbers.

Link to publication

\footnotetext{
General rights rights.

- You may freely distribute the URL identifying the publication in the public portal. please follow below link for the End User Agreement:

www.umlib.nl/taverne-license

Take down policy

If you believe that this document breaches copyright please contact us at:

repository@maastrichtuniversity.nl

providing details and we will investigate your claim.
}

Copyright and moral rights for the publications made accessible in the public portal are retained by the authors and/or other copyright owners and it is a condition of accessing publications that users recognise and abide by the legal requirements associated with these

- Users may download and print one copy of any publication from the public portal for the purpose of private study or research.

- You may not further distribute the material or use it for any profit-making activity or commercial gain

If the publication is distributed under the terms of Article $25 \mathrm{fa}$ of the Dutch Copyright Act, indicated by the "Taverne" license above, 


\section{Family history of mental conditions in the preventive paediatric primary care: is it really used? Case of the Netherlands}

Elena V Syurina (e.syurina@maastrichtuniversity.nl) ${ }^{1}$, Kristien Hens ${ }^{2}$, Wybo J Dondorp ${ }^{2}$, Frans JM Feron ${ }^{1}$

1.Department of Social Medicine, School for Public Health and Primary Care (CAPHRI), Faculty of Health, Medicine and Life Sciences, Maastricht University, Maastricht, The Netherlands

2.Department of Health, Ethics and Society, School for Public Health and Primary Care (CAPHRI), Faculty of Health, Medicine and Life Sciences, Maastricht University, Maastricht, The Netherlands

\section{Keywords}

Current practice, Family history, Health

determinants, Mental health, Paediatrics, Primary care

\section{Correspondence}

Elena V Syurina, Universiteitssingel 40-West, 6229 ER Maastricht, PO Box 616, 6200 MD Maastricht,

The Netherlands.

Tel: +31-43-38-82206 |

Fax: +31-43-38-81241 |

Email: e.syurina@maastrichtuniversity.nl

\section{Received}

20 July 2013; revised 9 October 2013; accepted 21 November 2013.

DOI:10.1111/apa.12521

\begin{abstract}
Aim: Many child-onset mental health diseases have strong epigenetic links, but no genetic tests are yet available for them. Family history (FH) information in paediatric primary care should be promoted to assist decision-making. This study aims to explore the extent of the real-life use of the $\mathrm{FH}$ for mental health issues by paediatric physicians.

Methods: The medical records of 474 children (31.5\% female), referred to the specialised mental health care services in the Netherlands, were used. Data were retrospectively extracted from the medical files, according to a list of 15 criteria regarding the use of $\mathrm{FH}$ information.

Results: The FH was explored in the form of a diagnosis and was presented at birth in $88.3 \%$ of cases and in half of the files at 5 years. Negative $\mathrm{FH}$ and the age of relatives at the time of diagnosis were virtually not mentioned. FH was present in more reports from the specialists, than in referral letters.

Conclusion: Despite the high importance of $\mathrm{FH}$ for primary paediatric care, this study shows that $\mathrm{FH}$ is underreported in practice. We should promote structural $\mathrm{FH}$ taking to increase how often it is used to treat children who do not meet criteria for definitive diagnosis.
\end{abstract}

\section{INTRODUCTION}

Mental health diseases and disorders constitute a considerable burden for the population (1). According to a European study, one in four people in Europe will meet some criteria for a mental health condition at some point in life (2).

Many common mental health issues have a strong genetic link. Unfortunately, most evidence in the field focuses on adult-onset diseases. For instance, schizophrenia is linked to genes such as DISC1, DTNBP1, NRG1, DRD2, HTR2A and COMT (3). Recent studies reveal considerable evidence supporting the existence of genes determining a predisposition to bipolar disorder (4). But a similar picture can be observed in most prevailing paediatric psychiatric disorders, for instance, attention deficit hyperactivity disorder.

Unlike simple monogenetic disorders, mental health disorders are usually associated with a much larger number of genes, which have a cumulative effect if linked to certain environmental influences. Thus, the development of the majority of diseases is not linear: addition of different components, such as environmental exposure, stress and genetic vulnerability, can contribute to growing into deficit and ultimately developing a disease (Fig. 1). On the other hand, having protective factors can prevent getting a diagnosis and diminish symptoms over time.

As it is difficult to link psychiatric disorders to genes, it might be more beneficial to look at the genetic profile of a child within his or her environment, during both the symptom management and diagnosis phases (5). Genetic screening tests have become increasingly available, but they only provide information about child's genetic profile, without considering environmental factors. One easy way

\section{Key notes}

- Family history (FH) is an important source of information that can assist decision-making and treatment of children who do not meet the criteria for mental health diagnosis.

- $\quad \mathrm{FH}$ provides knowledge about both the genetic profile of the child and his or her environment and lifestyle.

- Its current use is inconsistent and can be improved by structural integration of research results in preventive primary paediatric care practice. 


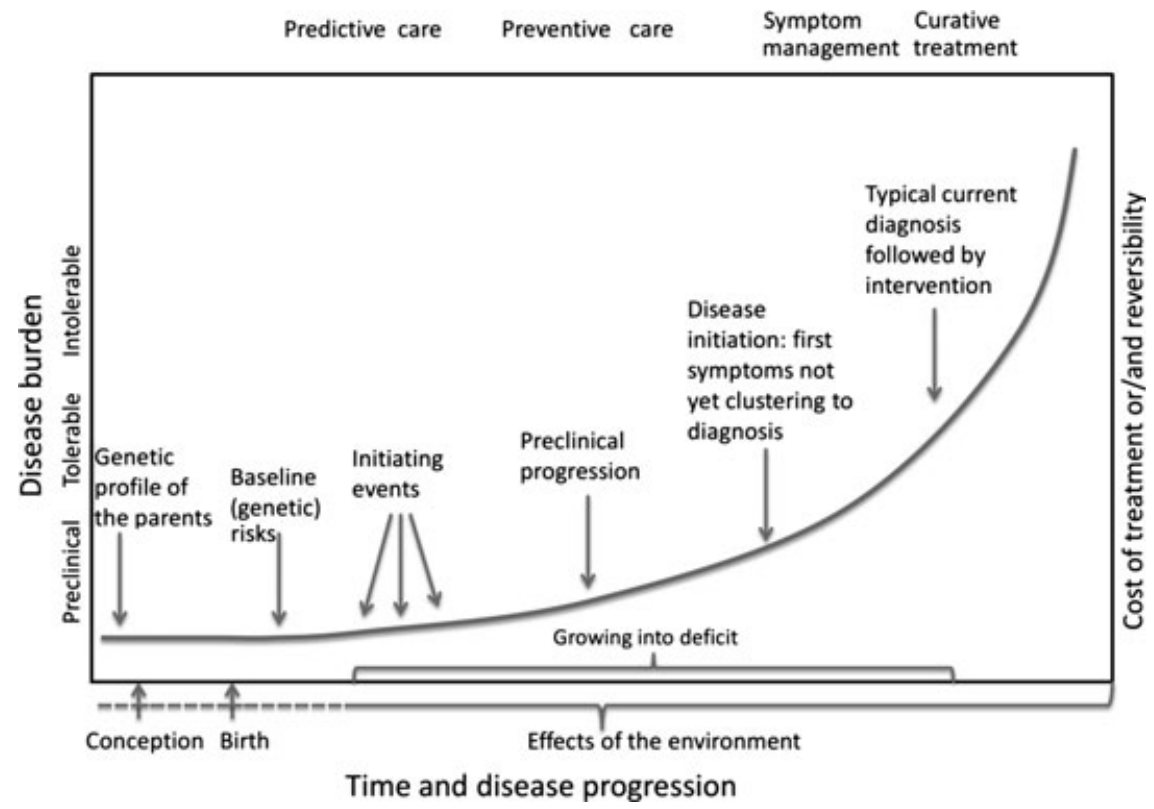

Figure 1 Adaptation of Snyderman's curve representing growing into deficit and developing common complex diseases.

to combine the genetic and the environmental information is recording the family history $(\mathrm{FH})$. It can provide data on the presence or absence of certain diseases in the family and describe common habits and lifestyles (6). FH is currently used by psychiatrists in clinical practice to facilitate the diagnostic process (7). However, paediatric care has several levels, starting with preventive paediatric primary care (PPPC) practices. Here, specialists are the first to see children and parents and are also the first to express concerns regarding development. It is useful for them to have a full assessment of the situation, including the $\mathrm{FH}$. This can help physicians to take pre-emptive and preventive actions (8).

This present work describes the current situation in a local Dutch community reading the utilisation of $\mathrm{FH}$ information in the everyday practice. Data that were analysed cover the period of the last 5 years.

In the Netherlands, PPPC services are provided free of charge to all children, from birth to 19 years, living in the country. PPPC professionals monitor the physical and mental health and development of the child, try to prevent diseases, provide symptom management and refer the child in case disease develops.

Our goal is to explore the extent to which FH is used, with regard to mental health issues, by the PPPC physicians in their everyday practice. One sub question is how FH use differs between the PPPC physicians and the specialists in the hospital settings.

Before starting this analysis, we hypothesised that $\mathrm{FH}$ is underreported in the PPPC practice compared with the reports of secondary care professionals. We also expected that a positive $\mathrm{FH}$, presence of diagnosis, is recorded more often than a negative one, absence of disease. In case of a positive $\mathrm{FH}$, we expected not to find the age of onset of diseases, despite the fact that this could be important for assessing a child's condition and prognosis. A possible correlation between whether $\mathrm{FH}$ is taken at primary or secondary healthcare facilities was investigated.

\section{METHODOLOGY}

We used the medical records of children who were referred for the specialised mental health care. The records were extracted from the archive of the RPHS South Limburg: GGD Zuid Limburg in Maastricht. Selection of the records was performed according to the presence or absence of the Child Behaviour Checklist (CBCL). CBCL is a screening tool that is used to identify children with upcoming problems. Presence or absence of a definitive diagnosis did not influence the selection process. Extracted records were screened for the FH taken at birth, mentioning of family anamnesis during the visit discussing first symptoms and in referrals to mental health specialists. The findings were later analysed using the list of 11 criteria of SPSS Statistics version 19 (IBM ${ }^{\circledR}$ SPSS $^{\circledR}$ Statistics 19$)$.

\section{Study population}

We used data from paediatric consultations (children aged 4-19 years) present in the registries of the RPHS in the city of Maastricht. We screened all records of children whose parents were asked to fill in the CBCL in the last 5 years ( January 01, 2007-January 01, 2012). In the Netherlands, all children are first screened using the strengths and difficulties questionnaire and, if any problems are detected by this tool, the parents and/or teachers are asked to fill in CBCL. Thus, we had a selection of the children with mental health complaints. This resulted in a list of 1247 children from cohorts from 1989 to 2005 . The decision was made to 
include the generations from 1998 to 2002, because these children would be around the age of onset of the mental health issues at the moment of research. The final list consisted of 474 records.

\section{Data extraction and ethical aspects}

All records were screened by a master student of medicine and a $\mathrm{PhD}$ researcher under the responsibility and supervision of the RPHS-physicians involved in the care of the children whose data were analysed. The data were coded with the use of a website Psychic Science that provided random digits. The table linking the digits to personal data was safely stored in the RPHS building. In accordance with the RPHS's privacy rules and the personal data protection act of The Netherlands, all parents were informed about the possible use of their files for various research and were given the opportunity to refuse. If no record of refusal was available in the file, we assumed agreement. The research design was approved by the Medical Research Ethics Committee of the Academic Hospital in Maastricht, prior to the start of the investigation (registration number: METC-12-4-049; 2 May 2012).

\section{Comparison criteria list and process of analysis}

To both assess how often FH is used in everyday practice and to examine how exactly it is taken, we developed a set encompassing 15 criteria. For our analysis, we used demographic information: year of birth, sex, socio-economic status and took account of where the FH was recorded in the child's file:general file, referral letter, etc. For this purpose, reports of two regular contact moments were screened:

1 the first visit of the nurse after birth results of which are presented to the physician and kept in the medical file

2 the first visit of the child to the RPHS. This happens around the fifth birthday, as between ages of 0 and 4 the child is under the attention of the infant welfare centre.

Other options included a reference letter to the mental health specialist, a report from the specialist back to the RPHS physician and notes about FH in the records of other visits. We also screened how $\mathrm{FH}$ is mentioned in the files: in the form of the exact diagnosis or the comparison of the symptoms (e.g. the father recognises his own learning difficulties in his child). In the literature used for this research, there is general agreement on the importance in keeping the FH up to date (9). Thus, we controlled for the number of updates of $\mathrm{FH}$ in the file. To assess the FH, we collected information about the highest degree of consanguinity. The last two factors of analysis were the presence of negative FH (absence of diseases) and notation of age of onset of diseases in relatives (Appendix S1).

\section{Statistical analysis}

Initial analysis of the data was performed using descriptive statistics in SPSS 19.0. The Pearson chi-square test was used to identify significant correlations within the data.

\section{RESULTS}

Our sample included 474 children born between 1998 and 2002 , and the sample included more boys than girls $(66.5 \%)$. The majority of the children were from the middle SES families. For descriptive statistics see Table 1.

In almost all records (95.0\%), FH was taken during the first visit after birth, which takes place $\sim 2$ weeks after birth. Absence of the FH happened because children were not born in the Netherlands or the papers were missing. Cases where nothing was marked on the FH part of the file without an explanation were rare (nine files).

Majority of files $(61.7 \%)$ contained FH data taken at the age of 5 . We observed the correlation between the birth year and the presence or absence of a FH at $5\left(\chi^{2}=209.874\right.$; $\mathrm{p}=0.000$ ). This is explained by the questionnaires used by RPHS-Maastricht at that time. Initially, questionnaires included one question about the absence-presence of certain diseases in the family. After the organisational changes in 2002, this question was deleted from the list. Our analysis shows that incorporation of $\mathrm{FH}$ in the questionnaire increases the probability that relevant information will be recorded in the file.

We found evidence that FH was more often taken at the specialised healthcare visits than in the PPPC settings. It was taken in $54.2 \%$ of reports from the specialists, while only $27.2 \%$ of referral letters mentioned this information. More information about location of $\mathrm{FH}$ within the file can be found in Table 2 .

When FH information was reported in the files, this was mostly carried out in the form of the diagnosis, not symptoms. Symptoms were mentioned in $18.6 \%$ of files and were usually noted in the form of: 'Mother recognizes behavior of the child in his father'. Symptoms were mostly asked during the secondary care visits (9.5\%), 3.4\% of records contained symptom records in the referral letter, and in $2.7 \%$ it was mentioned in more than one place. Still the numbers are relatively low.

Mostly information about second- and third-degree relatives was taken (63.2 and 26.4\%, respectively). Detailed

\begin{tabular}{lr}
$\begin{array}{l}\text { Table } 1 \text { Descriptive statistics } \\
\text { Variable }\end{array}$ & No. (\%) \\
\hline Sex & \\
$\quad$ Male & $315(66.5)$ \\
$\quad$ Female & $159(33.5)$ \\
Years of birth & \\
1998 & $65(13.7)$ \\
1999 & $92(19.4)$ \\
2000 & $123(25.9)$ \\
2001 & $97(20.5)$ \\
2002 & $97(20.5)$ \\
Socio-economic level & \\
Low & $111(23.4)$ \\
Middle & $190(40.1)$ \\
High & $159(33.5)$ \\
Missing & $10(2.1)$ \\
\hline
\end{tabular}




\begin{tabular}{|c|c|c|}
\hline Referral status & Location of $\mathrm{FH}$ & N (\%) \\
\hline \multirow[t]{5}{*}{ Not referred } & No FH & $12(2.53)$ \\
\hline & RPHS forms & 201 (42.40) \\
\hline & $\begin{array}{l}\text { Referral letter from RPHS physician } \\
\text { to secondary care }\end{array}$ & $3(0.63)$ \\
\hline & $\begin{array}{l}\text { Report from secondary care specialist } \\
\text { to RPHS physician }\end{array}$ & $3(0.63)$ \\
\hline & RPHS file & $12(2.53)$ \\
\hline \multirow[t]{5}{*}{ Referred } & No FH & $6(1.26)$ \\
\hline & RPHS forms & $252(53.16)$ \\
\hline & $\begin{array}{l}\text { Referral letter from RPHS physician to } \\
\text { secondary care }\end{array}$ & $28(5.90)$ \\
\hline & $\begin{array}{l}\text { Report from secondary care specialist } \\
\text { to RPHS physician }\end{array}$ & $77(16.24)$ \\
\hline & RPHS file & $17(3.58)$ \\
\hline
\end{tabular}

\begin{tabular}{|c|c|}
\hline $\begin{array}{l}\text { Degree of } \\
\text { consanguinity }\end{array}$ & N (\%) \\
\hline 1 & 28 (5.9) \\
\hline 2 & $287(60.5)$ \\
\hline 3 & $120(25.3)$ \\
\hline 4 & $18(3.8)$ \\
\hline 5 & $1(0.20)$ \\
\hline Missing & $20(4.2)$ \\
\hline
\end{tabular}

information about the number of degrees can be found in Table 3.

The analysis of the full data uncovered that in the vast majority of cases, FH was updated at least once. However, it is important to bear in mind that during several years, $\mathrm{FH}$ was incorporated in the structure of the questionnaire that all parents were supposed to fill in when the child was 5 years old. This questionnaire was counted as one of the updates. If we exclude the 5-year questionnaire from the count of updates, we see that no updates of $\mathrm{FH}$ were carried out in $72.4 \%$ of cases.

If we exclude cases in which the 5-year-old questionnaire was filled in, we have less power, as we decrease the number of participants being analysed. Then only $35.7 \%$ of cases had at least one update of FH. This proves that if the update of FH is not institutionally positioned in the plan of the consultation meeting, chances of FH to be updated are diminishing. Statistics on the number of updates can be found in Table 4.

We discovered that $\mathrm{FH}$ was rarely mentioned in the minutes of the consultations (5.9\% of records). It was found either in the structured questionnaires, where it could not be avoided, or in the referral letters and reports from the specialists. Some of the neuropsychological reports contained FH information in a separate chapter. Even when the FH was taken, health professionals virtually never noted the age of onset of diseases in the relatives (1.5\% of files).

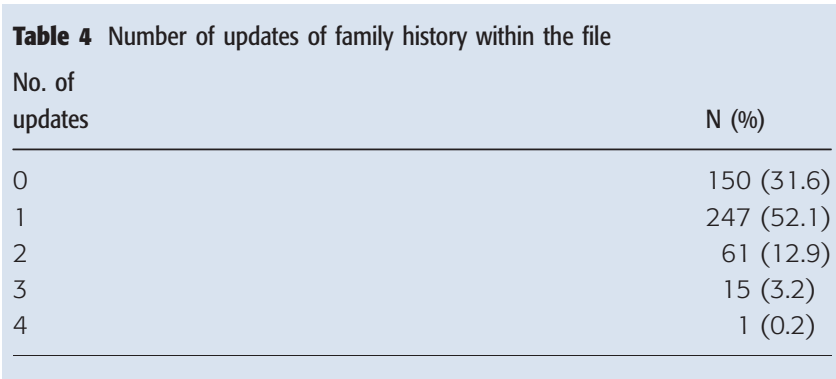

Negative FH was almost never mentioned (91.5\% of files); however, specialists tended to note it more often than primary healthcare physicians (4.3 and 2.4\%, respectively). Our analysis also identified a significant interaction between FH in the referral letter and in specialists' reports $\left(\chi^{2}=14.227 ; \mathrm{p}=0.000\right)$.

\section{DISCUSSION AND CONCLUSIONS}

The current study aimed at identifying the level of the current use of FH information in PPPC practice. This research was designed bearing in mind the clear advice of the American Academy of Pediatrics to make use of such information (8).

When interpreting the results, it is important to bear in mind several limitations of the study. First, the study was of a retrospective nature. However, the choice of a prospective study design could have increased a chance of socially desirable actions. Second, there is a possibility that PPPC physicians do ask the $\mathrm{FH}$, but in case of negative answer, they fail to record it in the file. According to several international recommendations, negative $\mathrm{FH}$ is also very important and should be mentioned. The fact that it is not put in the file may potentially complicate specialists' work. Next, our case selection mechanism was based on filling in the CBCL that screens for (develop)-mental issues. The picture may be different for other types of disorders. It is also possible that not all children who have difficulties filled in the CBCL. However, CBCL is the most used screening tool in the Netherlands for these kind of disorders, thus we suppose that it is advised by physicians in the vast majority of cases with potential problems.

The sample of the study was predominantly male. One possible explanation can be the different nature of mental health issues in boys and girls. As females tend to have more internalising problems, they may develop later in life and be less evident to the environment (10).

The most striking issue identified during present research was underreporting of the FH in PPPC. The fact that there is no obligatory form for reporting this kind of information makes it less likely to be remembered by the physician during the consult. When structurally embedded in the protocol (first home visit at around 2 weeks after birth), it massively improved the rate of reporting.

Secondary care specialists are in general more likely to mention the FH in their reports. Notation of FH in the referral letter from a PPPC physician to the specialists 
makes it more likely for $\mathrm{FH}$ to be asked again during the secondary care consults.

In the PPPC files, mostly second- and third-degree relatives are mentioned. Although it would be better to have a more complete $\mathrm{FH}$ picture of the environment of the child, usually this degree of detail is acceptable as it includes data about a wider range of relatives: cousins, uncles, grandparents. Information about more distant relatives is seldom reported, usually in cases of very serious and rare disorders.

The findings of present study are important in preparation for the shift towards a personalised approach in PPPC (11). One of the possible explanations of underuse of $\mathrm{FH}$ information can be limited knowledge available to health professionals about the utility of such information: physicians do not use it due to uncertainty of its utility. Secondary care specialists take FH more often. This can be due to the fact that they are more aware of the degree of heritability of the disease.

The role of the PPPC physicians is not to diagnose, but to make a decision whether the appearing symptoms are signals of a larger problem or a benign developmental variation. A recent study showed that many common mental health conditions bear the same genetic variant (12). Thus, it is very difficult to design genetic-based innovations for use in primary and secondary prevention. $\mathrm{FH}$ information can be used as an additional tool in decision-making and symptom management $(5,6,13,14)$.

Before FH use can be fully integrated into the PPPC system, it is important to resolve several issues. First, steps need to be taken to ensure that the privacy of patients and their family members is respected (15). For instance, it is important to ensure that information about $\mathrm{FH}$ is not used for health insurance purposes, as such discrimination is often feared by stakeholders (16) or that children are not discriminated against in school.

Next, it is important to formulate guidelines not only for collecting the $\mathrm{FH}$, but also for determining how and to what extent this information can be used in paediatric practice. Finally, before designing any kind of FH tool, it is important to ask potential users about their preferences. Once guidelines for PPPC physicians are specified and their wishes about the tool are implemented, they would be able to use the FH background of their patients more actively. FH will help not only to identify children at risk, but also review the protective mechanisms children might have. This may help avoiding misdiagnosis. It is important that use of $\mathrm{FH}$ does not change the daily routine of the physicians, but rather fine-tune it. However, one should not limit the range of stakeholders to just physicians. It is known that the genomic health literacy level currently is not optimal (17). It is possible that many parents do not pay enough attention to questions regarding $\mathrm{FH}$; thus, educating them about the benefits their children could get from an optimal use of this tool might improve their motivation.

\section{References}

1. Kessler R, Aguilar-Gaxiola S, Alonso J, Chatterji S, Lee S, Ormel J, et al. The global burden of mental disorders: an update from the WHO World Mental Health (WMH) surveys. Epidemiol Psichiatr Soc 2009; 18.1: 18-23.

2. Alonso J, Angermeyer MC, Bernert S, Bruffaerts R, Brugha TS, Bryson $\mathrm{H}$, et al. Prevalence of mental disorders in Europe: results from the European Study of the Epidemiology of Mental Disorders (ESEMeD) project. Acta Psychiatr Scand 2004; 109: 21-7.

3. Gejman PV, Sanders AR, Kendler KS. Genetics of schizophrenia: new findings and challenges. Annu Rev Genomics Hum Genet 2011; 12: 121-44.

4. McGuffin P, Rijsdijk F, Andrew M, Sham P, Katz R, Cardno A. The heritability of bipolar affective disorder and the genetic relationship to unipolar depression. Arch Gen Psychiatry 2003; 60: 497-502.

5. Claassen L, Henneman L, Janssens ACJW, Wijdenes-Pijl M, Qureshi N, Walter FM, et al. Using family history information to promote healthy lifestyles and prevent diseases; a discussion of the evidence. BMC Public Health 2010; 10: 248.

6. Rich EC, Burke W, Heaton CJ, Haga S, Pinsky L, Short MP, et al. Reconsidering the family history in primary care. J Gen Intern Med 2004; 19: 273-80.

7. Sullivan PF, Magnusson C, Reichenberg A, Boman M, Dalman C, Davidson M, et al. Family history of schizophrenia and bipolar disorder as risk factors for autismfamily history of psychosis as risk factor for ASD. Arch Gen Psychiatry 2012; 69: 1099-103.

8. Green RF. Summary of workgroup meeting on use of family history information in pediatric primary care and public health. Pediatrics 2007; 120(Suppl 2): S87-100.

9. Trotter TL, Martin HM. Family history in pediatric primary care. Pediatrics 2007; 120(Suppl. 2): S60-5.

10. Rosenfield S, Smith D. Gender and mental health: do men and women have different amounts or types of problems? A handbook for the study of mental health: social contexts, theories, and systems. Cambridge: Cambridge University Press, 2010: 256-67.

11. Snyderman R, Yoediono Z. Perspective: prospective health care and the role of academic medicine: lead, follow, or get out of the way. Acad Med 2008; 83: 707-14.

12. Smoller JW, Craddock N, Kendler K, Lee PH, Neale BM, Nurnberger JI, et al. Identification of risk loci with shared effects on five major psychiatric disorders: a genome-wide analysis. Lancet 2013; 381: 1371-9.

13. Frezzo TM, Rubinstein WS, Dunham D, Ormond KE. The genetic family history as a risk assessment tool in internal medicine. Genet Med 2003; 5: 84-91.

14. Kanetzke EE, Lynch J, Prows CA, Siegel RM, Myers MF. Perceived utility of parent-generated family health history as a health promotion tool in pediatric practice. Clin Pediatr (Phila) 2011; 50: 720-8.

15. Appelbaum P. Law \& psychiatry: genetic discrimination in mental disorders: the impact of the genetic information nondiscrimination act. Psychiatr Serv 2010; 61: 338-40.

16. O'Daniel J, Haga S, Willard H. Considerations for the impact of personal genome information: a study of genomic profiling among genetics and genomics professionals. J Genet Couns 2010; 19: 387-401.

17. Syurina EV, Hens K, Feron FJM. Literature review: use of family history for primary paediatric care as the next step towards use of genomics in healthcare. Curr Pediatr Rev 2013; in press.

\section{SUPPORTING INFORMATION}

Additional Supporting Information may be found in the online version of this article:

Appendix S1 Full list of variables used for analysis of information from the medical records. 